\title{
A Remembrance of Raymond E. Spier, 1938-2018
}

\author{
Stephanie J. Bird ${ }^{1}$
}

๑) Springer Nature B.V. 2018

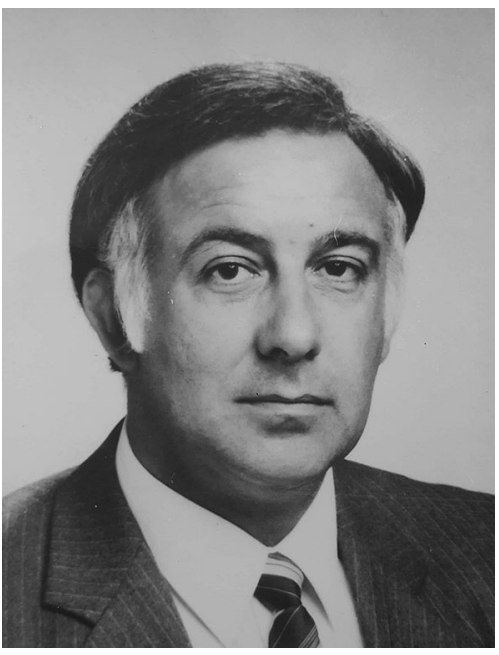

Sadly, Ray Spier died suddenly and unexpectedly on April 28 after a brief illness. He would have turned 80 on December 3. He was a big man, a powerhouse, a dynamo. More than that he was a presence. Whether in a small meeting or a major conference, one knew Ray was there, always willing to share his views, his perspective, his experience. I think a good measure of what drove him was his view that the world could be better if people worked together as a community. Along with his love of family, Ray's dedication to community was noted by his sons, Emmet and Avi at his graveside, and also interwoven in the eloquent and moving letter his daughter Dania read at his funeral.

He was a man of big ideas and goals: an "irreverent trail-blazer" from humble beginnings. Encouraged by teachers and his inspiring uncle, he applied himself to his studies and won a scholarship to Oxford. There he pursued the emerging field of biochemistry "because [he] wanted to know more about what life is, how it works, its origin and evolution...." His doctoral thesis focussed on biochemical mechanisms that controlled development and, as he said, "issues in the general area of 'control' became a central theme about which I hung the various endeavours that constituted the rest of my career." (Spier 2018)

\footnotetext{
${ }^{1}$ Unless otherwise noted, this quotation and those below are from an invited, autobiographical essay "Looking at controls and control systems" written in March of 2018 and provided by his daughter Dania Spier Fried (Spier 2018).
}

Stephanie J. Bird

sjbird@mit.edu

1 Wrentham, MA, USA 
In the mid-1960s, he followed his doctoral degree with a diploma in the then emerging field of biochemical engineering because he "regarded [himself] as uneducated insofar as [he] could make a practical contribution to the wellbeing of the world and its people [and] ... jumped at the opportunity to take a novel course ... that could make [him] into a useful contributor to human progress." (Spier 2018)

His early professional focus was on "the World Food Problem", and later on, "the prophylactic approach to human health care", in particular, vaccine development and production. This work took him to the US and the private sector, and ultimately brought him back to Britain and academia. During this period Ray founded and became Editor-in-Chief of the journals Vaccine (1983) and Cytotechnology (1987), as well as co-Editor-in-Chief of Enzyme and Microbial Technology (1986).

In the early 1990s, Ray "was attracted to the up and coming area of Science and Technology Ethics-where Ethics is a control system based on the use of words." (Spier 2018) I met Ray in early 1993 when he attended a workshop on teaching ethics in science and engineering. ${ }^{3}$ In his voluble, proactive and energetic way, Ray made himself known and at the end of the conference suggested a possible transatlantic project on science and engineering ethics. Several months later, in the fall of 1993, Ray called from the UK, proposing that we start a journal. Ray's enthusiasm was infectious. He persuaded me, explaining that, from his experience with the journal Vaccine, editing this new journal would not require more than half-a-day every couple of weeks (this turned out to be a rather substantial underestimation!). It was increasingly apparent that there was a real and growing need for explicit, open and on-going discussion of the values and ethical principles that underlie scientific research and engineering practice, as well as the ethical, legal and social policy implications associated with the application of research findings and new technologies. So, with Merilyn Spier (Ray's amazing wife and a professional architect) as our publisher, Opragen Publications was established and the three of us set about laying the foundation for Science and Engineering Ethics. Ray and I recruited members for an international editorial advisory board and solicited manuscripts for the first issues, and Meri provided essential steadying and an additional measure of integrity, compassion and creative insight to the process. Over the last 25 years the journal has grown immensely, becoming part of Springer (now Springer Nature) and adding several colleagues and layers of technology. Throughout, the three of us have worked together, and with our editors and editorial advisory board, to produce the journal that is Science and Engineering Ethics.

Each of Ray's professional accomplishments highlights his concern for the serious problems of the world and its people, and recognition of the possibility of making the world a better place. All along the way, Ray saw the value of building community and he pursued it. Ray's major contribution to the academic world is his

\footnotetext{
2 "The provision of nutritious protein was the key to the enhancement of the nutritional status of those in the Developing World". (Spier 2018)

3 "Teaching Ethics in Science and Engineering: Why, What and How", a 3-day symposium held in Boston, Massachusetts in conjunction with the 1993 annual meeting of the American Association for the Advancement of Science (AAAS), that I co-organized with Penny Gilmer (Florida State University) and Terry Bynum (Southern Connecticut State University).
} 
legacy of community embodied in his instrumental role in the founding of a professional society and through journals, especially Science and Engineering Ethics which, like Vaccine, has made a substantial impact on the scholarship of the field.

At his passing, our colleagues have lamented his loss, as well as celebrated his contributions to our community: "a valued colleague and friend", " such a character and a breath of fresh air in our meetings"," such vision and energy", "so much wonderful work and he made such a difference in our world", "a great tree that fell in the forest”. He continues to inspire us and he will be missed.

\section{References}

Spier, R. E. (2018). Looking at controls and control systems. Human Vaccines and Immunotherapeutics. https://doi.org/10.1080/21645515.2018.1460530. 